TIAGO MOLINA FERREIRA

OFERTA PÚBLICA DE DISTRIBUIÇÃO DE VALORES MOBILIÁRIOS:
O REGIME DE REGISTRO OBRIGATÓRIO E HIPÓTESES DE DISPENSA

Dissertação de Mestrado

Orientadora: Professora Dra. Juliana Krueger Pela

UNIVERSIDADE DE SÃO PAULO

FACULDADE DE DIREITO

SÃO PAULO - SP

2018 
TIAGO MOLINA FERREIRA

\section{OFERTA PÚBLICA DE DISTRIBUIÇÃO DE VALORES MOBILIÁRIOS: O REGIME DE REGISTRO OBRIGATÓRIO E HIPÓTESES DE DISPENSA}

Dissertação apresentada à Banca Examinadora do Programa de Pós-Graduação da Faculdade de Direito da Universidade de São Paulo, como exigência parcial para obtenção do título de Mestre em Direito, na área de concentração de Direito Comercial, sob orientação da Professora Dra. Juliana Krueger Pela.

UNIVERSIDADE DE SÃO PAULO

FACULDADE DE DIREITO

SÃO PAULO - SP

2018 
Ferreira, Tiago Molina.

Oferta pública de distribuição de valores mobiliários: o regime de registro obrigatório e hipóteses de dispensa / Tiago Molina Ferreira; Orientadora: Juliana Krueger Pela - São Paulo, 2018.

409 .

Dissertação (Mestrado - Programa de Pós-Graduação em Direito Comercial) - Faculdade de Direito, Universidade de São Paulo, 2018.

1. Mercado de valores mobiliários. 2. Oferta pública de distribuição de valores mobiliários. 3. Divulgação de informações. 4. Registro obrigatório. 5. Hipóteses de dispensa de registro obrigatório. I. Pela, Juliana Krueger, orient. II. Título. 
"In short, Congress did not take away from the citizen 'his inalienable right to make a fool of himself'. It simply attempted to prevent others from making a fool of him."

Louis Loss. Fundamentals of Securities Regulation (1988). 
FERREIRA, Tiago Molina. Oferta pública de distribuição de valores mobiliários: o regime de registro obrigatório e hipóteses de dispensa. 2018. 409p. Dissertação de Mestrado. Faculdade de Direito da Universidade de São Paulo, São Paulo, 2018.

\section{RESUMO}

Essa dissertação tem por objeto examinar a regulação das ofertas públicas de distribuição de valores mobiliários sob duplo enfoque, teórico e prático. Sob o ponto de vista teórico, procura-se discutir as razões pelas quais a regulação das ofertas públicas foi estruturada em torno da política de ampla divulgação de informações. Quanto ao enfoque prático, o objetivo é apresentar de forma organizada e sistematizada, e analisar criticamente, as diferentes hipóteses de registro, além das dispensas de requisitos e dispensas do próprio registro de distribuição de valores mobiliários previstas na regulação Brasileira. Para atingir esse objetivo, a dissertação está dividida em duas partes. Na primeira parte, o Capítulo I é dedicado a analisar as duas principais teorias de regulação das ofertas públicas de distribuição de valores mobiliários, quais sejam, a teoria da regulação por meio da política de ampla divulgação de informações e a teoria da regulação substantiva, assim como são apresentadas algumas propostas de modelos alternativos, como a escolha de regulação pelos emissores e a regulação sobre investidores. O Capítulo II da primeira parte tem por escopo demonstrar que o registro de distribuição e o registro de emissor são apenas instrumentos para exigir o cumprimento da política de ampla divulgação de informações. Por se tratar de mero instrumento, a exigência de registro de distribuição poderá ser dispensada ou atenuada quando for demonstrado que o público investidor foi adequadamente informado por outros meios que não pelo registro. A segunda parte da dissertação é dedicada ao estudo da regulação brasileira sobre as ofertas públicas de distribuição. O Capítulo I discute o que caracteriza oferta pública de distribuição de valores mobiliários no Brasil e quando o registro pode ser dispensado em razão do relacionamento previamente existente entre emissores, ofertantes e investidores. O Capítulo II mostra como a CVM administra a política de ampla divulgação de informações no mercado de capitais local, tanto pela aplicação do sistema de duplo registro, quanto pela imposição de obrigações e de um amplo regime de responsabilidades às instituições intermediárias. Os Capítulos III, IV, V e VI da segunda parte estão focados na análise da regulação em espécie, aplicável aos diferentes regimes de registro e de dispensa de registro de ofertas públicas. Por último, são apresentadas as principais conclusões alcançadas por meio desse trabalho e algumas sugestões de aprimoramento da regulação vigente no Brasil.

Palavras-chave: Mercado de valores mobiliários. Oferta pública de distribuição de valores mobiliários. Divulgação de informações. Registro obrigatório. Hipóteses de dispensa de registro obrigatório. 
FERREIRA, Tiago Molina. Securities public offering: the registration rule and its exemptions. 2018. 409p. Master's in Law Dissertation. Faculty of Law of the University of São Paulo, São Paulo, 2018.

\begin{abstract}
The purpose of this thesis is to analyze the regulation on securities public offerings by a twofold approach: theoretical and practical. Under the theoretical perspective, the discussion aims the reasons why the full disclosure model was adopted as a policy to regulate securities public offerings. On the practical side, the goal is to present, in an organized and systemic basis, the different hypothesis of registration, together with the exemption of requirements and exemptions of registration of public securities offerings in Brazilian regulation. To achieve such purpose, the dissertation is divided in two sections. In the first section, Chapter I analyses the major theories regarding regulation of public securities offering, which are the full disclosure theory and the substantive theory, as well certain alternative proposals for models of regulation, such as the issuer's choice and the regulation upon investors. Chapter II of first section is focused on demonstrating that the registration of public offerings and the registration of issuers are only tools to enforce the full disclosure policy. As being only an instrument, the mandatory rule of registration of securities public offerings should be waived or softened when shown that the investors got appropriately informed by any other means than the register. The second section is devoted to the Brazilian regulation over securities public offerings. Chapter I discuss when an offer could be considered as a securities public offering under Brazilian regulation and when the registration rule would be exempted based on the previous relationship amongst issuers, offerors and investors. Chapter II shows how CVM manages the full disclosure policy in the local capital markets, both by demanding compliance to the dual-system of registrations and imposing several obligations and responsibilities on the market intermediaries. Chapters III, IV, V and VI of the second section encompasses the examination of the regulation applicable to the regimes of registration and exemptions from the registration rule of public offerings. At the end, the main conclusions reached by this dissertation are presented, as well as some suggestions to improve the regulation in force in Brazil.
\end{abstract}

Key words: Securities market. Securities public offerings. Full Disclosure. Registration rule. Exemptions from the registration rule. 


\section{SUMÁRIO}

\section{INTRODUÇÃO}

1. Apresentação e delimitação do tema.....

2. Plano de exposição e divisão do trabalho.

PARTE I.

A TEORIA DA REGULAÇÃO DAS OFERTAS PÚBLICAS DE DISTRIBUIÇÃO DE VALORES MOBILIÁRIOS

\section{CAPÍtULO I. A RACIONALIDADE DA REGULAÇÃO DAS OFERTAS PÚBLICAS DE DISTRIBUIÇÃO DE VALORES MOBILIÁRIOS ................................5}

1. O embate entre o modelo de regulação substantiva e o modelo de ampla divulgação de informações

2. O modelo de ampla divulgação de informações como paradigma da regulação das ofertas públicas de distribuição . 16

2.1. A tutela do público investidor. 18

2.1.1. Suporte para decisão informada, refletida e independente 18

2.1.2. Problemas na produção e divulgação de informações como falha de mercado: a informação como bem público..... 22

2.2. A tutela do mercado 26

2.2.1. A importância da confiança para o adequado funcionamento do mercado de valores mobiliários 26

2.2.2. Formação pública do preço dos ativos negociados ........................229

2.2.3. Alocação eficiente de recursos......................................................... 33

2.2.4. Monitoramento público e privado............................................... 37

3. Críticas ao modelo de ampla divulgação de informações como paradigma da regulação das ofertas públicas de distribuição.....

3.1. O mercado naturalmente oferecerá informações aos investidores.

3.2. O investidor não é melhor protegido pela atual política de ampla divulgação de informações 
3.3. A certificação das ofertas por meio da cadeia de intermediários torna desnecessária a imposição da política de ampla divulgação de informações.

3.4. Subsídio indevido a autoridades e instituições intermediárias ......................... 48

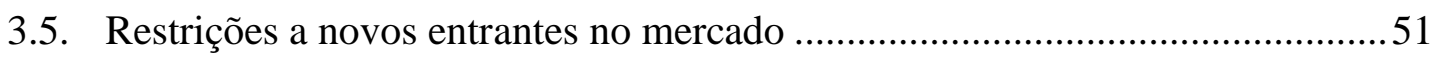

3.6. Divulgação de informações comercialmente e concorrencialmente sensíveis .52

4. Alternativas ao modelo de ampla divulgação de informações .53

4.1. A escolha do regime de divulgação de informações pelos emissores 54

4.2. A substituição da regulação dos emissores pela regulação dos investidores

\section{CAPÍTULO II. O REGISTRO COMO INSTRUMENTO DE APLICAÇÃO DA POLÍTICA DE AMPLA DIVULGAÇÃO DE INFORMAÇÕES................................. 72}

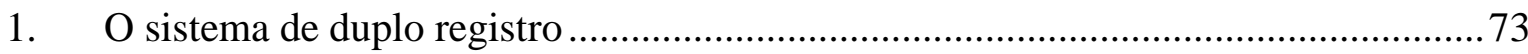

2. Dispensa ou simplificação do processo de registro de oferta pública de distribuição de valores mobiliários 76

2.1 Acesso prévio a informações que seriam divulgadas por meio do registro da oferta pública.....

2.2 Independentemente do acesso prévio a informações, quando o valor do investimento for pouco relevante

2.3 Independentemente do acesso a prévio a informações, quando o número de investidores for limitado 84

CAPÍtUlO I. A CARACTERIZAÇÃO DE OFERTA PÚBLICA DE DISTRIBUIÇÃO DE VALORES MOBILIÁRIOS NO DIREITO BRASILEIRO ....85

1. Meios de exteriorização da oferta pública: esforços de colocação destinados ao público investidor em geral 88

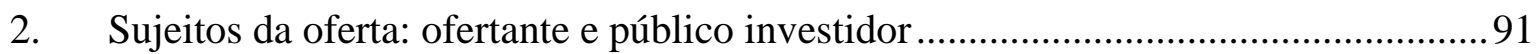

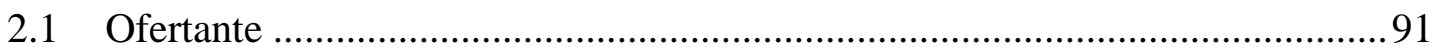

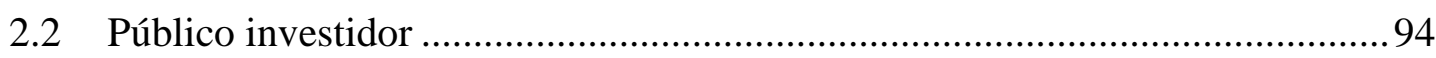

2.2.1 Oferta pública para empregados .............................................. 99 


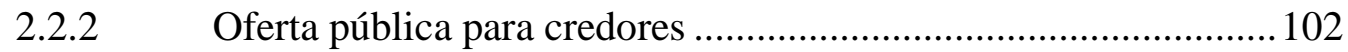

2.2.3 Oferta pública para acionistas ou cotistas ................................. 105

2.2.4 Oferta pública para clientes bancários ......................................110

2.2.5 Oferta pública para número limitado de investidores ................. 111

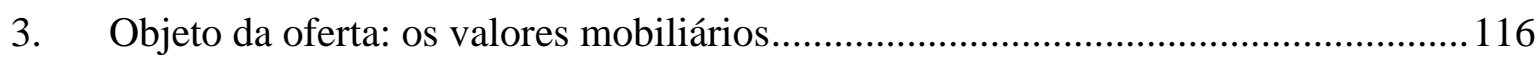

3.1 A construção da definição de valores mobiliários ........................................ 116

3.2 Dualidade regulatória: valores mobiliários e o tratamento dispensado aos títulos de dívida pública federal, estadual ou municipal e títulos cambiais de responsabilidade de instituições financeiras ............................................................................ 127

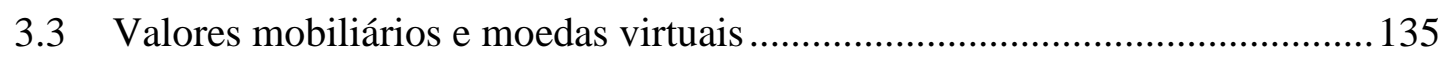

4. Ofertas públicas e ofertas privadas: identificação de oferta pública de distribuição de valores mobiliários

\section{CAPÍtUlO II. A ADMINISTRAÇÃO DA POLÍTICA DE AMPLA DIVULGAÇÃO DE INFORMAÇÕES....................................................................145}

1. Registro de oferta pública de distribuição e registro de emissor: relacionados, mas independentes

2. Ofertas públicas de distribuição iniciais e subsequentes: diferentes preocupações e

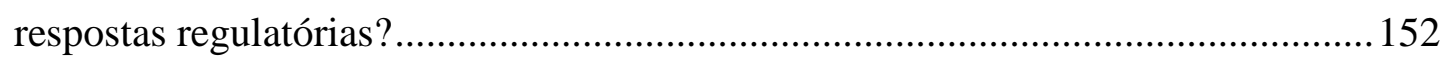

3. Registro de oferta pública de distribuição: decisão vinculada da CVM?.................153

4. Consequências da realização de distribuição de valores mobiliários sem prévio registro

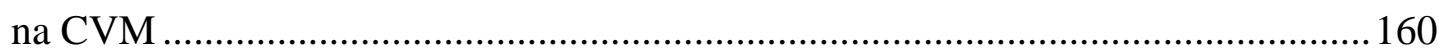

5. O papel das instituições intermediárias nas ofertas públicas de distribuição............164

\section{CAPÍTULO III. REGIME GERAL DE REGISTRO OBRIGATÓRIO DE OFERTAS PÚBLICAS 170}

1. Regime geral de registro de ofertas públicas de distribuição de valores mobiliários:

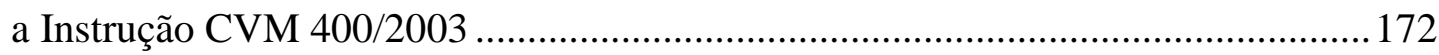

1.1 Etapa 1: da preparação até o protocolo do pedido de registro da oferta ......... 173

1.1.1 Prospecto da oferta.............................................................. 173

1.1.2 Consulta a potenciais investidores antes do início da oferta (pilot

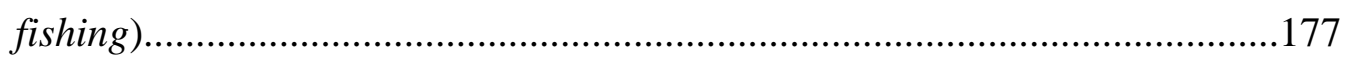

1.1.3 Divulgação da decisão de realização da oferta pública................177 
1.2 Etapa 2: análise e processamento do pedido de registro da oferta. 178

1.2.1 Processamento do pedido de registro da oferta 178

1.2.2 Lote adicional (hot issue) e lote suplementar (green shoe) 181

1.2.3 Coleta de intenções de investimentos (bookbuilding). 182

1.3 Etapa 3: do registro à liquidação da oferta 183

1.3.1 Alteração, modificação ou revogação da oferta 184

1.3.2 Encerramento da oferta: distribuição total ou parcial 186

\section{CAPÍTULO IV. REGIME GERAL DE REGISTRO SIMPLIFICADO DE} OFERTAS PÚBLICAS

1. Procedimento geral de registro simplificado de ofertas públicas: a Instrução CVM $471 / 2008$

2. Ofertas públicas secundárias de ações admitidas à negociação em mercados organizados: art. $6^{\circ}$, caput, da Instrução CVM 400/2003 192

3. Ofertas públicas primárias de sobras de ações admitidas à negociação: art. $6^{\circ}, \S^{\circ}$, da Instrução CVM 400/2003

4. Ofertas públicas de emissores com grande exposição ao mercado: os arts. $6^{\circ}$-A e $6^{\circ}$-B da Instrução CVM 400/03

5. Ofertas públicas vinculadas a programas de distribuição de valores mobiliários: arts. 11 a 13 da Instrução CVM 400/2003 200

6. Ofertas públicas de distribuição de letras financeiras vinculadas a programas de distribuição contínua de valores mobiliários: arts. 13-A a 13-F da Instrução CVM $400 / 2003$ 203

7. Ofertas públicas de debêntures padronizadas: a Instrução CVM 404/2004 208

\section{CAPÍtULO V. REGIME GERAL DE DISPENSA DE REQUISITOS E DE REGISTRO DE OFERTAS PÚBLICAS.

1. Regime geral de dispensa de requisitos e de registro de ofertas públicas por solicitação do interessado: o art. $4^{\circ}$ da Instrução CVM 400/2003

1.1 Hipóteses de dispensa de requisitos e de registro de oferta pública 216

1.1.1 Valor unitário dos valores mobiliários ofertados e valor total da

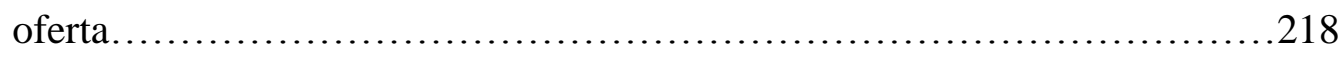

1.1.2 Plano de distribuição de valores mobiliários 
1.1.3 Distribuição em mais de uma jurisdição ...................................222

1.1.4 Características da oferta de permuta ........................................223

1.1.5 Publico destinatário: localidade geográfica, quantidade e sofisticação....................................................223

1.2 Requisitos do procedimento de registro que mais são dispensados pela CVM: a Deliberação CVM 476/2005.

1.3 Ausência de hipóteses gerais de dispensa automática de registro e a necessidade de revisão das normas da CVM.

2. Regime geral de dispensa automática de registro: o art. $5^{\circ}$ da Instrução CVM 400/2003

2.1 Ofertas públicas de ações de propriedade de pessoas jurídicas de direito público: o art. $5^{\circ}$, inciso I, da Instrução CVM 400/2003. 232

2.2 Ofertas públicas de lote único e indivisível de valores mobiliários: o art. $5^{\circ}$, inciso II, da Instrução CVM 400/2003. 238

3. Ofertas públicas com esforços restritos de distribuição: a Instrução CVM 476/2009

3.1 Valores mobiliários passíveis de distribuição com esforços restritos. 244

3.2 Público destinatário limitado: investidores profissionais 246

3.3 Procedimento de distribuição. 250

3.4 Negociação em mercado secundário dos valores mobiliários objeto de ofertas públicas com esforços restritos. 255

\section{CAPÍTULO VI. REGIMES ESPECIAIS DE OFERTAS PÚBLICAS ..............262}

1. Oferta pública de cotas de fundos de investimento ................................................263

1.1 Regras gerais: a Instrução CVM 555/2014 ...............................................268

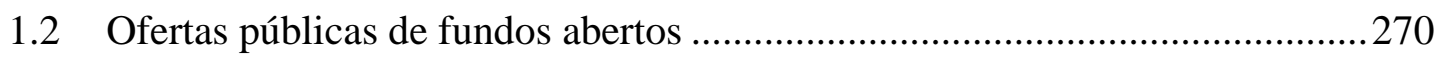

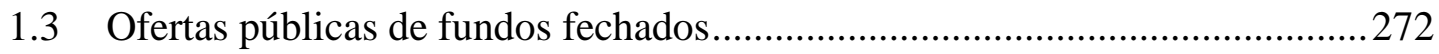

1.3.1 Ofertas públicas de cotas de FIP: a Instrução CVM 578/2016 ...275

1.3.2 Ofertas públicas de cotas de Fundos de Investimento Imobiliário (FII): a Instrução CVM 472/2008 279

1.3.3 Ofertas públicas de cotas de Fundos de Investimento em Direitos Creditórios (FIDC) e de Fundos de Investimento em Cotas de Fundos de 
Investimento em Direitos Creditórios (FICFIDC): a Instrução CVM $356 / 2001$

2. Oferta pública de Certificados de Recebíveis Imobiliários (CRI): a Instrução CVM $414 / 2004$

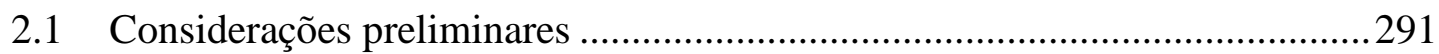

2.2 Formas de distribuição pública de CRI........................................................297

2.2.1 Variações aos procedimentos de distribuição das Instruções CVM 400/2003 e 476/2009.

2.2.2 Variações apenas no procedimento de distribuição da Instrução CVM 400/2003

2.2.3 Variações apenas no procedimento de distribuição da Instrução CVM 476/2009 305

3. Oferta pública de Certificados de Recebíveis do Agronegócio (CRA): a aplicação subsidiária da Instrução CVM 414/2004. 306

4. Oferta pública de Notas Promissórias: a Instrução CVM 566/2015 ….....................312

4.1 Notas Promissórias passíveis de distribuição pública.

4.2 Variações ao procedimento de distribuição da Instrução CVM 400/2003 .....316

5. Oferta pública de Certificado de Depósito de Valores Mobiliários (BDR): a Instrução CVM 332/2000

5.1 Programas de BDR

5.1.1 BDRs Patrocinados Nível I, II e III. 323

5.1.2 BDR não patrocinados 327

6. Oferta pública de Contratos de Investimento Coletivo Hoteleiro (CIC hoteleiro)... 328 6.1 Deliberação CVM 734/2015 333

6.2 Proposta de nova instrução normativa: Edital de Audiência Pública SDM 08/2016.

6.2.1 Interações com a Instrução CVM 400/2003 e com a Deliberação CVM 734/2015

6.2.2 Registro de distribuição e registro do emissor 341

6.2.3 Limitação do público investidor .344

6.2.4 Marcos temporais. 346

6.2.5 Dispensa de contratação de instituições intermediárias e o papel dos corretores de imóveis . 347 
7. Oferta pública de Certificados de Potencial Adicional de Construção (CEPAC): a Instrução CVM 401/2003

8. Oferta pública de Certificados de Investimento Audiovisual (CAV): a Instrução CVM 260/1997

9. Oferta pública de valores mobiliários de sociedades empresárias de pequeno porte: a Instrução CVM 588/2017

10. Oferta pública de Certificado de Operações Estruturadas (COE): a Instrução CVM $569 / 2015$

11. Oferta pública de Contratos de Investimento Coletivo (CIC): a Instrução CVM $296 / 1998$

CONCLUSÃO

1. Síntese Conclusiva 384

2. Considerações finais 399

BIBLIOGRAFIA .401 


\section{INTRODUÇÃO}

\section{Apresentação e delimitação do tema}

A elaboração dessa dissertação foi guiada por dois principais objetivos.

Em primeiro lugar, compreender, com base na análise das teorias discutidas na doutrina, por quais motivos se decidiu regular as ofertas públicas de distribuição de valores mobiliários por meio do emprego de uma política pública específica, pautada no ideal de ampla divulgação de informações, quando haviam e continuam existindo outras possibilidades de abordagem da matéria, como a denominada regulação de mérito ou regulação substantiva.

Em segundo lugar, verificar de que forma a racionalidade da política de ampla divulgação de informações, formadora e base para a regulação das ofertas públicas de distribuição de valores mobiliários nas jurisdições analisadas, está refletida no atual conjunto de normas que formam o sistema de registros, incluindo hipóteses de dispensas de requisitos e hipóteses de dispensa do próprio registro de oferta pública de distribuição de valores mobiliários no direito brasileiro.

Paralelamente a esses dois objetivos, e como subproduto da análise da regulação em espécie brasileira, pretendeu-se também apresentar de forma organizada e sistematizada as inúmeras hipóteses de simplificação, dispensa de requisitos e dispensa de registro de distribuição pública de valores mobiliários.

Por seguir uma lógica diferente das ofertas públicas de distribuição, o exame das ofertas públicas de aquisição de valores mobiliários ${ }^{1}$ não faz parte do objeto dessa dissertação de mestrado. Com efeito, enquanto nas ofertas públicas de distribuição os investidores são incitados a comprar valores mobiliários, nas ofertas públicas de aquisição os investidores são convidados a vender valores mobiliários de sua propriedade. A troca da

\footnotetext{
1 Sobre o tema, vide CARVALHOSA, Modesto. Oferta pública de aquisição de ações. Rio de Janeiro: IBMEC, 1979; OIOLI, Erik Frederico. Oferta pública de aquisição do controle de companhias abertas. São Paulo: Quartier Latin, 2010. PRADO, Roberta Nioac. Oferta pública de ações obrigatória nas S.A: tag along. São Paulo: Quartier Latin, 2005.
} 
posição jurídica de investidor para a de vendedor faz com que as preocupações da regulação sejam sensivelmente diferentes ${ }^{2}$.

A abordagem a ser dada a este trabalho caminha de uma parte geral e mais abstrata, na qual serão analisados os principais fundamentos e aspectos relacionados à regulação das ofertas públicas de valores mobiliários, até chegar a um exame mais específico, verticalizado e aprofundado das hipóteses de registro e dispensa de registro de ofertas públicas de distribuição de valores mobiliários.

\section{Plano de exposição e divisão do trabalho}

Essa dissertação de mestrado está dividida em duas Partes, cada uma subdivida em capítulos e itens próprios.

A Parte I tem como objeto examinar os fundamentos e os objetivos para o exercício, pelo Estado, de sua atuação reguladora no âmbito das ofertas públicas de distribuição de valores mobiliários por meio da imposição do cumprimento da política de ampla divulgação de informações.

O Capítulo 1 da Parte I está dedicado especificamente a discutir o porquê da escolha da política de ampla divulgação de informações como método para regulação não apenas das ofertas públicas de distribuição de valores mobiliários, mas também do próprio mercado de capitais.

O Capítulo 2, por sua vez, procura relacionar a política de ampla divulgação de informações com o principal instrumento utilizado pelo Estado para assegurar o seu cumprimento: o sistema de duplo registro, de distribuição de valores mobiliários e de emissor de valores mobiliários. No Capítulo 2 também são discutidas algumas hipóteses

2 Se nas ofertas públicas de distribuição ao investidor deve ser franqueado acesso a todas as informações do emissor, de suas atividades e negócios, para avaliar não apenas se o preço e as condições de venda dos valores mobiliários estão adequadamente demonstradas, mas também se o investimento poderá gerar os retornos esperados, nas ofertas públicas de aquisição a preocupação é mais no sentido de garantir que o investidor possa examinar se o preço oferecido reflete o verdadeiro valor dos valores mobiliários e, em caso positivo, que o ofertante tenha os recursos para liquidar a operação de compra. 
teóricas em que o registro poderia se mostrar dispensável tendo em vista as características da oferta pública analisada.

A Parte II está inteiramente voltada para o exame da legislação e da regulação brasileiras sobre as ofertas públicas de distribuição de valores mobiliários. Além de discutir como os pressupostos teóricos da Parte I influenciaram e se refletem, na prática, na regulação nacional, a Parte II também pretende contribuir para o estudo da matéria por meio da sistematização das inúmeras hipóteses de dispensa de requisitos e do próprio registro de oferta pública de distribuição de valores mobiliários.

Para tanto, não se poderia deixar de analisar cada uma das quase duas dezenas de instruções normativas da CVM que disciplinam as ofertas públicas de distribuição de valores mobiliários, com o objetivo de compará-las entre si e daí tentar extrair a racionalidade do nosso sistema de registro obrigatório e hipóteses de simplificação e de dispensa.

A esse respeito, depois do exame das instruções normativas, de vários julgados do Colegiado da CVM e de inúmeras manifestações das áreas técnicas da autarquia, consolidouse o entendimento de que a sistematização deveria ser feita em torno de dois critérios: (a) obrigatoriedade de registro de distribuição e suas exceções (obrigatoriedade de registro, simplificação do processo de registro e dispensa de registro) e (b) tipo de valor mobiliário oferecido ao público investidor (qualquer tipo de valor mobiliário [regime geral] ou tipos específicos [regimes especiais]).

Nesse contexto, a proposta apresentada nessa trabalho divide as normas aplicáveis sobre a matéria criadas pela CVM em (a) regime geral de registro obrigatório de ofertas públicas (Instrução CVM 400/2003), (b) regime geral de simplificação de registro de ofertas públicas (Instrução CVM 400/2003 e Instrução CVM 471/2008), (c) regime geral de dispensa de registro de ofertas públicas (Instrução CVM 400/2003 e Instrução CVM 476/2009) e (d) regimes especiais de ofertas públicas (no qual se discute instruções que cuidam de aspectos específicos da oferta pública de determinados tipos de valores mobiliários).

Dessa forma, o Capítulo I da Parte II busca examinar como se caracteriza a oferta pública de distribuição de valores mobiliários segundo a legislação e regulação vigentes no 
Brasil, e quando a oferta pública de distribuição de valores mobiliários pode estar isenta de registro em razão do relacionamento prévio existente entre o emissor ou o ofertante e o público investidor.

O Capítulo II analisa aspectos específicos e particularidades dos meios pelos quais a CVM procura fazer cumprir a política de ampla divulgação de informações no contexto nacional, desde a administração do sistema de duplo registro (registro de distribuição e registro de emissor) até a imposição de uma série de deveres, obrigações e responsabilidades às instituições intermediárias que participam dos esforços de distribuição ao lado dos ofertantes.

Os Capítulos seguintes, III, IV, V e VI, cuidam, respectivamente, do regime de registro obrigatório, do regime de simplificação do registro obrigatório, do regime de dispensas de requisitos para o registro e de dispensa de registro obrigatório e, por fim, dos regimes especiais de realização de ofertas públicas de distribuição de valores mobiliários, criados em razão das particularidades dos valores mobiliários oferecidos ao público investidor.

Em cada um desses capítulos, apresentamos um panorama geral e prático de cada uma das instruções normativas analisadas, assim como buscamos ressaltar os principais pontos de crítica identificados a partir da comparação realizada entre todas as normas e de seu cotejo com a teoria da regulação das ofertas públicas de distribuição debatida ao longo da Parte I.

Por último, apresentamos uma breve conclusão, na qual são retomados os principais aspectos discutidos ao longo dessa dissertação e pontuados alguns apontamentos finais sobre o tema. 


\section{CONCLUSÃo}

\section{Síntese Conclusiva}

Sem prejuízo do detalhamento das teorias e argumentos apresentados ao longo dessa dissertação, a seguir é apresentada uma breve síntese sobre as principais conclusões alcançadas nesse trabalho.

1. Por meio do recorte temporal efetuado em 1929, no contexto da crise da bolsa de valores de Nova Iorque, e da identificação dos argumentos apresentados para justificar o arcabouço regulatório criado com a finalidade de evitar que as práticas abusivas e fraudes contra investidores voltassem a ocorrer, sobretudo na doutrina norte-americana, pôde se perceber que a política de ampla divulgação de informações que atualmente constitui a base da regulação das ofertas públicas de distribuição nas jurisdições analisadas nem sempre reinou sozinha.

2. Com efeito, alguns juristas reclamavam que ao Estado deveria recair a responsabilidade e a competência por escolher, entre os empreendimentos que lhe eram apresentados para registro de distribuição pública de valores mobiliários, quais seriam merecedores da autorização de captar publicamente recursos do público investidor e quais não teriam a mesma sorte.

3. O resultado da regulação substantiva ou de mérito sobre as ofertas públicas de distribuição proposta por esses autores seria atribuir ao Estado o poder de, a seu critério, restringir ou impedir a possibilidade de investimentos em emissores em relação aos quais se entendesse não existir condições suficientes para acessar a poupança popular.

4. Ainda que sob o argumento de que os investidores seriam melhor protegidos por meio de uma participação mais ativa do Estado no processo de registro e de fiscalização das ofertas públicas de distribuição de valores mobiliários, prevaleceu a orientação, influenciada pelo ideário liberal, de que cada indivíduo deveria ter asseguradas autonomia e liberdade de decidir, por si próprio, onde e como investir suas finanças pessoais, suportando todos os ônus e responsabilidades de sua decisão de investimento. 
5. Ao concluir que caberia a cada pessoa, e não o Estado, construir sua decisão de investimento, passou-se a defender que a regulação das ofertas públicas de distribuição deveria servir como mero suporte no processo de tomada de decisão de investimento pelos investidores, algo que seria concretizado por meio da imposição a ofertantes e emissores do dever de ampla, completa e quase irrestrita divulgação de informações a seu respeito e a respeito dos valores mobiliários oferecidos publicamente.

6. Por meio da aplicação da política de ampla divulgação de informações, verificamos que a preocupação do Estado está mais em assegurar o acesso a informações e menos em garantir que o público investidor possui capacidade e conhecimento suficientes para processar e compreender os materiais divulgados por emissores e ofertantes.

7. Essa ainda é, até hoje, uma das principais críticas ao modelo atual de regulação das ofertas públicas de distribuição, haja visto a tendência de cada vez mais ampliar as obrigações de disclosure, sem, contudo, ter a certeza, baseada, por exemplo, em estudos ou análises empíricas, de que mais informações podem contribuir positivamente para o processo de tomada de decisão de investimento.

8. Pelo contrário, alguns dos autores analisados mostram que o excesso de divulgação de informações pode fazer com que os investidores prefiram adotar uma decisão de investimento menos racional, pautada em critérios emocionais ou em outras variáveis, do que fariam se tivessem acesso a uma quantidade limitada, porém mais útil de dados sobre o emissor e os valores mobiliários oferecidos.

9. Um dos constantes desafios do modelo de regulação de ofertas públicas através da política de divulgação de informações é, nesse passo, criar instrumentos e mecanismos que permitam verdadeiramente informar o público investidor, e não apenas despejar sobre ele uma quantidade cada vez mais vasta de dados e informações sem qualquer tipo de consideração a respeito de sua utilidade.

10. Para se certificar de que o público investidor tem à disposição os documentos, informações e dados de que possa precisar para formar sua decisão de investimento de 
maneira consciente, refletida e independente, o Estado passou a exigir o registro prévio tanto da oferta pública de distribuição, quanto do emissor de valores mobiliários.

11. O sistema de duplo registro é considerado como um dos instrumentos do Estado para fazer valer a política de ampla divulgação de informações nas ofertas públicas de distribuição de valores mobiliários. Considerando que o objetivo é informar o público investidor, o sistema de registros é apenas um dos meios para que essa finalidade possa ser alcançada, nunca um fim em si mesmo.

12. Apesar de ambas as modalidades de registro, de emissor e de distribuição pública, terem por produto final assegurar o cumprimento da política de ampla divulgação de informações, seus objetivos e pressupostos são diferentes.

13. Com efeito, enquanto o registro de distribuição pública visa informar o público destinatário de determinada oferta pública de distribuição a respeito do emissor e dos valores mobiliários oferecidos naquela oferta, o registro de emissor tem por escopo manter os investidores atuais e futuros informados a respeito das atividades do emissor e da performance dos valores mobiliários admitidos à negociação em mercados secundários regulamentados enquanto houver valores mobiliários passíveis de negociação pública em tais mercados regulamentados.

14. Em outras palavras, o alcance do registro de distribuição pública e de emissor não são os mesmos. O primeiro está limitado ao período da distribuição e ao conjunto de pessoas que formam o público destinatário da oferta. O segundo tem duração por tempo indeterminado e atinge todo o mercado de valores mobiliários, incluindo investidores atuais e futuros.

15. Por essa razão, apesar de estarem relacionados, o registro de distribuição pública e o registro de emissor não devem ser confundidos e, em nossa opinião, devem ser tratados de forma independente, o que influenciará os diferentes arranjos de registro e de dispensa de registro discutidos no âmbito da regulação brasileira.

16. No caso do registro de oferta pública de distribuição, sempre que for possível demonstrar que o público-alvo está devidamente informado antes do início dos esforços de 
venda, sem a necessidade de intervenção do Estado, terá sido atendido o objetivo que permeia a obrigatoriedade de registro, tornando-o, por conseguinte, dispensável.

17. A dispensa de registro de emissor, por sua vez, dependerá da verificação do interesse ou não do emissor em ter admitidos à negociação em mercados regulamentados os valores mobiliários de sua emissão. Em caso de resposta positiva, o registro de emissor não poderá ser, em princípio, afastado em razão da necessidade de continuamente manter o público investidor e o mercado de valores mobiliários informados, inclusive porque o acesso a informações é essencial para permitir a formação do preço de cotação dos valores mobiliários, a partir do qual as negociações em mercado de bolsa ou de balcão organizado serão realizadas.

18. Ainda no contexto da teoria da regulação das ofertas públicas de distribuição, discutiu-se outras situações em que a obrigatoriedade de registro de distribuição não se mostra imprescindível vis a vis outros objetivos da regulação do mercado de valores mobiliários, como o fomento do financiamento das atividades dos entes deficitários que se socorrem dessa forma de captação de recursos.

19. Entre as hipóteses discutidas estão a oferta pública de distribuição cujo valor total captado não é significante e cujo aporte de capital a ser feito por cada investidor individualmente não justifica movimentar todo o aparato regulatório estatal para exigir o prévio registro de distribuição. Também se examinou o caso de ofertas públicas destinadas a um número limitado de pessoas, em que eventual descumprimento da legislação aplicável teria reduzido potencial de afetação dos mercados organizados de valores mobiliários.

20. Dessa forma, procurou-se construir hipóteses teóricas em que a exigência de prévio registro de distribuição seria desnecessária e muitas vezes desproporcional ou incompatível com as particularidades da oferta pública em questão, inclusive com prejuízo a outros objetivos da regulação.

21. Concluída a análise sobre as razões pelas quais a regulação das ofertas públicas de distribuição foi estruturada a partir da política de ampla divulgação de informações, a Parte II teve por objeto examinar a legislação e regulamentação brasileiras sobre o tema, 
com enfoque nos pontos de aderência e de fricção com os fundamentos teóricos apresentados na Parte I.

22. Inicialmente, se discutiu o que caracteriza oferta pública de distribuição de valores mobiliários para os fins da regulação brasileira, o que pressupôs o exame de seus elementos objetivos (esforços de distribuição) e subjetivos (agentes envolvidos, ofertante e público investidor), além, é claro, do próprio estudo dos ativos que são ofertados publicamente, os valores mobiliários.

23. De modo a identificar se determinada oferta pode ser considerada oferta pública de distribuição de valores mobiliários, foi apresentada uma proposta de teste, dividido em três etapas consecutivas de validações: (a) em primeiro lugar, verificar se existe esforço de venda capaz de atingir o público investidor em geral; (b) em segundo lugar, confirmar que os destinatários dos esforços de venda da distribuição são pessoas residentes, domiciliadas ou constituídas no Brasil; e (c) por último, e em terceiro lugar, identificar se o objeto ofertado é composto por valores mobiliários nos termos da Lei 6.385/1976 ou por outros títulos que a legislação esparsa determina que sejam tratados tal como se fossem valores mobiliários.

24. Durante a discussão de como as ofertas públicas de distribuição de valores mobiliários são caracterizadas segundo a legislação e a regulação nacional, verificou-se que, no conceito de "público investidor em geral", a regulação excetua as pessoas que tenham prévia, estreita e habitual relação trabalhista, societária, creditícia ou comercial com o emissor ou com o ofertante e eventuais contratados ou partes relacionadas a esses.

25. Apesar de prever a ressalva, a Instrução CVM 400/2003 não disciplina a consequência da verificação de que o público investidor é formado por pessoas com prévia, estreita e habitual relação com o emissor. Por outro lado, as decisões do Colegiado da CVM discutidas no Capítulo I da Parte II mostram que essa é, na verdade, uma hipótese de dispensa de registro de distribuição por solicitação do interessado.

26. Assim, a despeito de serem ofertas públicas de distribuição de valores mobiliários, as ofertas destinadas a pessoas com prévia, estreita e habitual relação com o emissor ou com o ofertante podem ser dispensadas de registro pela CVM. 
27. Nesse caso, a oferta continua sendo pública, mas a regulação reconhece que a proximidade com o ofertante ou com o emissor tornam desnecessário o registro com base no pressuposto de que o público investidor já teve acesso às informações de que necessita para formar sua decisão de investimento.

28. Por isso, o teste completo de identificação de oferta pública de distribuição de valores mobiliários não é encerrado no momento em que se conclui tratar-se de oferta pública de distribuição de valores mobiliários segundo o ordenamento jurídico brasileiro, mas deve ir além e investigar também se tal oferta pode ou não ser dispensada de registro na CVM em razão de suas características.

29. Do ponto de vista do ofertante e do emissor, o que importa em termos práticos é justamente saber se a sua oferta estará sujeita às regras editadas pela CVM, de modo que seja possível se preparar e verificar a viabilidade de atendimento de todo o arcabouço regulatório criado em torno do tema.

30. Nos termos da atual regulação, somente será concedida dispensa de registro com base na existência de relação prévia, estreita e habitual com os investidores se o interessado provocar a análise da CVM.

31. Apesar disso, muitas situações sobre as quais parece haver o entendimento de que prescindem de registro (como, por exemplo, ofertas para atuais acionistas ou cotistas, ofertas para empregados de nível executivo ou gerencial, ofertas para credores relevantes, entre outras) poderiam ser tratadas pela CVM, na verdade, como hipóteses de dispensa automática de registro.

32. A revisão das instruções normativas da CVM para incluir novas hipóteses de dispensa automática de registro baseada na existência de relação prévia, estreita e habitual com o emissor ou o ofertante, traria maior segurança jurídica para ofertantes e emissores e evitaria gastos de recursos, tempo e energia desnecessários, assim como o risco de perder janelas de oportunidade em razão do período de espera até que a autarquia profira sua decisão final. 
33. Da mesma forma, e apesar de não ser uma hipótese de relação prévia, estreita e habitual com o emissor ou o ofertante, debateu-se a necessidade de se reconhecer a ausência de interesse em regular ofertas públicas cujo público investidor é limitado numericamente, dispensando, assim, o registro de distribuição na CVM.

34. Nesses casos, ainda que não se possa assegurar que o público investidor teve acesso a todas as informações que a regulação entende serem adequadas para a tomada de decisão de investimento, a restrição da quantidade de pessoas abordadas aponta para a maior proximidade com o emissor ou com o ofertante e para a necessidade de efetiva negociação dos termos da oferta com os investidores para que sua viabilização possa ser concretizada, o que implicaria, consequentemente, na divulgação de informações em extensão suficiente para que o investidor possa se decidir.

35. Da mesma forma, outra justificativa para a dispensa automática de registro seria o menor potencial lesivo apresentado por essas ofertas públicas de distribuição. Assim, ainda que ocorram fraudes ou descumprimentos, em razão da limitação do número de investidores abordados, seus efeitos provavelmente ficarão circunscritos e não afetarão o funcionamento normal dos mercados organizados de valores mobiliários.

36. Ainda sobre o tema caracterização de oferta pública de distribuição, o estudo da definição de valores mobiliários mostrou que determinados títulos de investimento, ainda que possam ser qualificados como valores mobiliários conforme sua definição geral e teórica (investimento de recursos em empreendimento coletivo do qual se espera obter retorno financeiro a partir do esforço de terceiros), foram excluídos do alcance da fiscalização e regulamentação da CVM por expressa disposição legal.

37. A esse respeito, a Lei 6.385/1976 determina que os títulos de dívida pública e os títulos de crédito de responsabilidade de instituição financeira não devem ser tratados como valores mobiliários, nem estão sujeitos à competência da CVM, mas sim do BCB, como autoridade reguladora do mercado financeiro e de capitais formado por títulos de dívida pública.

38. A existência de dualidade regulatória entre CVM e BCB, ou até mesmo de multiplicidade regulatória, se consideramos outros órgãos reguladores como a SUSEP, 
em oportunidades de investimento tão semelhantes e próximas umas das outras pode acabar por fazer com que se dê preferência e maior facilidade de acesso à poupança popular por meio de determinados instrumentos de investimento em detrimento de outros.

39. Por essa razão, além de se questionar a verdadeira motivação e os fundamentos para manutenção da divisão de competências entre CVM e BCB no campo do mercado de capitais, é preciso acompanhar com atenção de que forma a interação entre esses órgãos pode representar arbitragem regulatória em favor de determinados emissores ou iniciativas de captação de recursos em desfavor de outras. Esse é um tema que merece aprofundamento em trabalhos posteriores.

40. Superada a análise da definição de oferta pública de distribuição de valores mobiliários no direito brasileiro, passou-se a examinar como a política de ampla divulgação de informações é administrada localmente pela CVM.

41. A esse respeito, ratificou-se o entendimento exposto na Parte I de que o sistema de registro de ofertas públicas de distribuição e de registro de emissor é a principal ferramenta utilizada pela CVM para atingir tal finalidade.

42. Além de reforçar a necessidade de tratar separadamente os registros de oferta pública de distribuição e de emissor, defendemos o entendimento de que a Lei 6.385/1976 prevê que o registro da oferta pública de distribuição autoriza automaticamente o ofertante a utilizar o mercado de balcão não organizado para colocar os valores mobiliários junto ao público investidor, sem a necessidade de solicitar, concomitantemente ao registro da oferta pública de distribuição, o registro de emissor na CVM.

43. Dessa forma, seria permitido ao ofertante realizar a oferta pública de distribuição sem obter registro de emissor, conquanto os esforços de venda ficassem restritos ao mercado de balcão não organizado e os investidores fossem alertados de que após o encerramento da oferta os valores mobiliários comercializados não seriam admitidos à negociação em mercados regulamentados.

44. O registro como emissor na CVM somente passaria a ser necessário, por conseguinte, se houvesse interesse e intenção em obter autorização para ter valores 
mobiliários admitidos à negociação em mercado secundário depois da finalização da oferta pública. Caso contrário, apenas o registro de distribuição pública seria necessário, podendo ainda ser dispensado nas hipóteses previstas na regulação.

45. A decisão da CVM em registrar ou não determinada distribuição pública de valores mobiliários é vinculada e está limitada, como regra geral, a analisar aspectos formais de legalidade, como o atendimento do regime informacional aplicável ao tipo de oferta pública que se pretende realizar.

46. Apesar disso, identificamos na legislação e regulação algumas características e feições da regulação substantiva ou de mérito, como a possibilidade de a CVM indeferir o registro de distribuição por entender que o empreendimento que se pretende financiar por meio do mercado de capitais é inviável ou temerário.

47. Nesse caso, a opinião uníssona da doutrina, com a qual compartilhamos, é a de que somente em caráter excepcionalíssimo a CVM poderá usar a prerrogativa de indeferir a solicitação de registro de distribuição com base em características comercias ou operacionais do empreendimento, notadamente quando restar totalmente evidente que a mera aplicação da política de ampla divulgação de informações não é suficiente para assegurar a adequada proteção do público investidor.

48. Outros exemplos de aspectos de regulação de mérito encontrados nas normas da CVM são, na oferta pública de distribuição de CAVs, a limitação à $10 \%$ do montante da captação dos honorários e encargos de distribuição, e, nas ofertas públicas de sociedades empresárias de pequeno porte, a exigência de que o investidor líder e as sociedades empresárias de pequeno porte concedam tag along de venda de participação societária ou de controle aos investidores.

49. Além do sistema de duplo registro, outra forma de assegurar o cumprimento da política de ampla divulgação de informações discutida nesse trabalho é por meio da imposição de obrigações e responsabilidades aos agentes que atuam ao lado dos ofertantes nas ofertas públicas de distribuição de valores mobiliários, sobretudo as instituições intermediárias. 
50. Sobre esse aspecto, a regulação da CVM considera as instituições intermediárias como verdadeiros gatekeepers do sistema de regulação de ofertas públicas de distribuição, atribuindo uma série de deveres a essas entidades, como o de investigar se as informações divulgadas pelo ofertante são verdadeiras, precisas e completas, de assegurar que os investimentos sugeridos aos investidores sejam adequados ao seu perfil de investimento e de garantir que determinados produtos financeiros somente serão negociados por investidores profissionais ou qualificados, quando assim for determinado na regulação.

51. Em seguida, passou-se a analisar os regimes de registro e dispensa de registro de ofertas públicas de distribuição, divididos em regime geral de registro obrigatório, regime geral de simplificação do registro obrigatório, regime de dispensas de requisitos ou do próprio registro e regimes especiais.

52. O regime geral de registro obrigatório de ofertas públicas de distribuição é representado pela Instrução CVM 400/2003, que é utilizada como modelo para as demais instruções normativas editadas pela autarquia que disciplinam aspectos específicos de ofertas públicas de determinados tipos de valores mobiliários ou de operações com características singulares, igualmente sujeitas a registro na CVM.

53. A partir do panorama geral introduzido pela Instrução CVM 400/2003, que exige o registro da oferta pública, o registro do emissor e a participação obrigatória de instituições intermediárias integrantes do sistema de distribuição de valores mobiliários nas ofertas públicas, foram estabelecidos requisitos adicionais nas demais instruções normativas que disciplinam ofertas públicas de distribuição, quando se entendeu que a oferta pública em questão poderia representar mais riscos para os investidores, ou hipóteses de dispensa, quando a situação se invertia e a atuação do Estado poderia ser sensivelmente reduzida.

54. Dessa forma, há (a) ofertas públicas de distribuição de valores mobiliários que observam apenas a Instrução CVM 400/2003, (b) ofertas públicas que se submetem tanto à Instrução CVM 400/2003 quanto à instrução específica a respeito do tipo de valor mobiliário oferecido e, por fim, (c) ofertas públicas que não estão sujeitas à Instrução CVM 400/2003, nem mesmo subsidiariamente, sendo disciplinadas autonomamente por regras especiais. 
55. O primeiro passo rumo à dispensa de registro passa por sua simplificação. A esse respeito, a Instrução CVM 400/2003, nas hipóteses em que especifica, e a Instrução CVM 471/2008, que trata dos convênios celebrados pela CVM com entidades autorreguladoras responsáveis pela análise prévia de pedido de registro de distribuição, formam o assim denominado "regime geral de registro simplificado de ofertas públicas".

56. A principal razão para que o processo de registro de distribuição seja simplificado reside na circunstância de o emissor já estar registrado na CVM, o que implica cumprimento do regime informacional próprio dos emissores previsto na Instrução CVM 480/2009. Considerando que o emissor já possui registro de companhia aberta, o registro de distribuição pode ser simplificado na medida em que o mercado e o público investidor já possuem acesso a parte das informações e dados que lhe seriam disponibilizados por meio do registro de distribuição.

57. Ainda a esse respeito, é importante observar que as hipóteses de registro automático não se confundem com as hipóteses de dispensa automática de registro.

58. No primeiro caso, a oferta continua sujeita a registro na CVM, apesar de existir uma via mais rápida de análise de registro de distribuição, razão pela qual é denominado de "registro automático". Não obstante, o ofertante precisará observar as restrições, prazos, comunicações e procedimento tal qual um registro comum de oferta pública de distribuição de valores mobiliários.

59. No segundo caso, a oferta está isenta de registro, razão pela qual é tratada tal como se fosse uma oferta privada, exceto por eventuais comunicações e dados que devem ser reportados pela CVM conforme a hipótese aplicável. Por essa razão, quando se tratar de oferta pública automaticamente dispensada de registro, o ofertante estará sujeito, se for o caso, ao regime informacional mais brando dentre aqueles existentes para as ofertas públicas de distribuição.

60. Ao lado da dispensa automática de registro, existem também as hipóteses de dispensa de registro ou de requisitos do registro por solicitação do ofertante endereçada à CVM. Para esses casos, a oferta pública somente poderá ser iniciada depois que a CVM se manifestar favoravelmente a respeito da dispensa pleiteada ou o ofertante obter o registro de 
distribuição e cumprir com as demais regras aplicáveis da modalidade de oferta pública de distribuição que pretende realizar.

61. As hipóteses de dispensa de registro ou de requisitos para o registro em geral, que não estejam relacionadas a um determinado tipo de valor mobiliário, formam o que foi denominado nessa dissertação de mestrado como "regime geral de dispensa de requisitos e de registro de ofertas públicas”.

62. Conforme debatido no Capítulo V, o art. $4^{\circ}$ da Instrução CVM 400/2003 trata das principais hipóteses em que a CVM poderá dispensar requisitos para o registro ou o próprio registro da oferta pública de distribuição, entre os quais destacam-se o valor unitário e o valor total da oferta, a quantidade e à sofisticação do público investidor, assim como o plano de distribuição.

63. A principal crítica que se tem a esse respeito é a ausência de previsão de hipóteses de dispensa automática de registro quando verificadas determinadas circunstâncias que historicamente têm feito com que o Colegiado da CVM dispense o registro a pedido do interessado ou que já foram reconhecidas em diversas outras jurisdições como situações em que a manutenção da obrigatoriedade de registro seria desproporcional em relação aos demais objetivos que a regulação do mercado de valores mobiliários procura atingir.

64. Assim, ofertas públicas de distribuição de valores mobiliários destinadas a poucas pessoas, cujo valor unitário de investimento por investidor e total captado sejam baixos ou cujo valor unitário total seja mais elevado do que determinado patamar são exemplos de casos em que, na maioria das vezes, a intervenção regulatória do Estado não se justifica.

65. A determinação de que essas hipóteses estariam automaticamente dispensadas de registro de distribuição não apenas favorecia o desenvolvimento do mercado, ao permitir que determinadas iniciativas pudessem ser realizadas sem a preocupação de autuação dos envolvidos por parte da CVM, mas também liberaria a autarquia para dedicar seus escassos recursos humanos e financeiros em iniciativas de captação pública de recursos que poderiam verdadeiramente representar riscos para o mercado de valores mobiliários. 
66. Uma iniciativa que tem dado certo são as ofertas públicas com esforços restritos de distribuição. Disciplinadas pela Instrução CVM 476/2009, as ofertas públicas com esforços restritos de distribuição estão automaticamente dispensadas de registro de distribuição, mas só podem ser ofertadas a um número limitado de investidores profissionais e devem contar com a intervenção obrigatória de uma instituição intermediária.

67. A limitação ao número de investidores profissionais procurados por ocasião dos esforços restritos de distribuição e a possibilidade de que os valores mobiliários adquiridos possam ser transferidos para investidores qualificados somente depois de 90 dias da data de aquisição são os aspectos que, na nossa visão, deveriam ser revistos em eventual reforma da Instrução 476/2009.

68. Com efeito, se a oferta é limitada a investidores profissionais, que representam, no direito brasileiro, o segmento mais sofisticado e restrito de investidores, não parece fazer sentido impor adicionalmente um limite numérico de pessoas que possam ser abordadas. Em outras jurisdições analisadas, como a norte-americana e a europeia, a maioria das ofertas públicas destinadas a investidores sofisticados não está sujeita a qualquer limitação numérica.

69. No que diz respeito à restrição de participação de investidores qualificados no âmbito da oferta, a permissão para que passem a negociar com valores mobiliários depois de 90 dias da data de aquisição torna inócua a limitação de participação na oferta e soa como um contrassenso. Nesse caso, ou a CVM entende que os valores mobiliários oferecidos com esforços restritos de distribuição somente podem ser negociados entre investidores profissionais ou permite que os investidores qualificados possam aderir à oferta desde o início.

70. Ao longo dos estudos para a elaboração da Parte II, sobretudo o Capítulo VI, que discute os regimes especiais de ofertas públicas, uma das críticas que se pretendia fazer ao final dessa dissertação era justamente a grande quantidade e variedade de normas existentes para disciplinar as ofertas públicas de distribuição de valores mobiliários, o que dificultava não apenas a compreensão da matéria pelo intérprete, mas a própria manutenção da coesão e da unidade do sistema de regime de registro obrigatório e de suas hipóteses de dispensa. 
71. Ao cabo, a conclusão a que chegamos foi ligeiramente diferente. De maneira geral, é possível afirmar que o conjunto de instruções normativas editadas pela CVM que compõem o sistema de registro obrigatório e as hipóteses de dispensa reflete de maneira adequada as preocupações que embasam a teoria da regulação das ofertas públicas de distribuição de valores mobiliários.

72. A multiplicidade de normas da CVM não é, na verdade, fruto do trabalho de um regulador atabalhoado, mas justifica-se pela multiplicidade de tipos de valores mobiliários, cada um com particularidades e complexidades próprias, pelos diferentes meios para distribuição de valores mobiliários, pelas variações nos níveis de sofisticação do público investidor e pelas características dos emissores de valores mobiliários que se socorrem do mercado de capitais.

73. Conforme buscou se mostrar nesse trabalho, existem variáveis demais para serem apreendidas e positivadas. Não nos parece possível, portanto, imaginar o estabelecimento de apenas uma única instrução normativa ou a criação de uma espécie de "código único" para todas e quaisquer modalidades de ofertas públicas de distribuição dos mais variados tipos de valores mobiliários.

74. Isso não significa dizer, entretanto, que as diferentes instruções normativas criadas pela CVM não deveriam gravitar em torno de um mesmo eixo comum, a necessidade de adequada informação do público investidor, e variar conforme a interpretação de que a regulação deveria ser mais ou menos extensiva para assegurar o seu cumprimento.

75. Assim, quanto maior os riscos que a oferta pública de determinado valor mobiliário apresentar para o público-alvo ou para o adequado funcionamento dos mercados regulamentados de valores mobiliários, mais legitimidade os órgãos reguladores possuirão para intensificar a regulação e as limitações impostas à liberdade de atuação dos agentes privados.

76. A análise realizada ao longo da Parte II mostrou, todavia, que a regulação brasileira das ofertas públicas de distribuição nem sempre se manteve próxima do objetivo de proteção do público investidor através de sua adequada informação. 
77. Em muitas oportunidades, faltou, principalmente, coerência na postura da CVM quando procurou impor requisitos adicionais para o registro de distribuição de valores mobiliários ou para a criação de hipóteses de dispensa, que oscilou de conservadora e cautelosa para liberal e permissiva.

78. A esse respeito, por exemplo, não nos parece fazer sentido continuar a demandar o registro de ofertas públicas de baixíssimo valor, como é o caso das ofertas públicas de certificados de investimento audiovisual, em que se chegou a localizar registros de distribuição de montante total captado inferior a $\mathrm{R} \$ 20$ mil, e deixar produtos financeiros muito mais complexos, como os certificados de operação estruturada, isentos de registro de distribuição e de um regime informacional mais rígido simplesmente por se tratar de títulos de emissão exclusiva de instituição financeira.

79. No caso das ofertas públicas de valores mobiliários de sociedades empresarias de pequeno porte realizadas com dispensa de registro de distribuição, a CVM preferiu não sugerir aos participantes do mercado nem mesmo um regime informacional mínimo a ser seguido depois da conclusão dos esforços de distribuição, o que poderia favorecer e proteger o desenvolvimento dessas ofertas.

80. Da mesma forma, algumas instruções normativas parecem terem sido deixadas de lado pelo mercado e pela CVM, sendo que esta não se preocupou em revogá-las formalmente, apesar de não terem sido identificadas ofertas ou quaisquer procedimentos relacionados a elas nos últimos anos, o que gera dúvidas e insegurança jurídicas aos ofertantes, que não conseguem precisar qual norma devem observar. Esse é o caso das instruções que cuidam de ofertas públicas de contratos de investimento coletivo e de debêntures padronizadas.

81. Também existem uma série de aprimoramentos e ajustes que poderiam ser realizados para melhorar o tratamento das ofertas públicas discutidas no âmbito do regime especial de que tratou o Capítulo VI.

82. Exemplo disso é a inclusão da possibilidade de que ofertas públicas de cotas de fundos de investimento fechados estruturados possam se valer da hipótese de dispensa de registro automático prevista na Instrução CVM 555/2014, que disciplina os fundos não 
estruturados, em vez terem de se submeter ao procedimento de registro da Instrução 400/2003, quando não se tratar de oferta pública com esforços restritos de distribuição.

83. A propósito, essa proposta de revisão só se faz necessária porque a Instrução CVM 476/2009 impede que os esforços públicos restritos de distribuição sejam direcionados a investidores qualificados, limitando-os a investidores profissionais, o que, conforme demonstrado acima, é outro ponto que merece ser revisitado futuramente.

84. Apesar das críticas à postura da autarquia, as últimas instruções normativas criadas mostram maior maturidade e solidez do que as normas editadas no começo dos anos 2000. Isso aponta também para o fato de que não é apenas o mercado de valores mobiliários no Brasil que ainda está em evolução, mas também o próprio órgão regulador e os agentes privados que nele atuam.

\section{Considerações finais}

A sensação que se tem ao concluir esse trabalho é o de que ainda há muito o que ser feito para que o mercado de valores mobiliários brasileiro possa um dia ser tão robusto e desenvolvido quanto o Brasil espera e precisa.

Com a melhoria dos indicadores econômicos, o controle da inflação e a redução da taxa básica de juros, a expectativa é que as ofertas públicas de distribuição de valores mobiliários possam voltar a ser utilizadas como efetiva alternativa de captação de recursos por parte dos empresários brasileiros.

Quando o momento chegar, a regulação não pode ser mais um entrave para a tentativa de crescimento das empresas, o que reforça a necessidade de que estudos e discussões como a que essa dissertação procurou desenvolver sejam cada vez mais recorrentes.

No que diz respeito especificamente à regulação das ofertas públicas de distribuição, e como foi demonstrado ao longo de toda a Parte II, algumas instruções normativas da CVM merecem passar por um amplo processo de revisão por parte da 
autarquia, enquanto quase todas as demais podem ser objeto de ajustes e reparos pontuais com vistas a seu aprimoramento.

Além de adequar as atuais regras às experiências acumulados nos últimos anos, sobretudo no período de 2005 a 2008, quando houve grande incremento no número de ofertas públicas de distribuição e de listagem de emissores, é necessário sempre lembrar que o vetor proteção do investidor, através de sua adequada informação, deve vir acompanhado da viabilização do uso do mercado como uma forma efetivamente alternativa de captação de recursos para as atividades dos entes deficitários.

Por essa razão, e mais do que nunca, a atividade reguladora da CVM, que implica restrição da liberdade individual dos agentes privados, deve ser exercida apenas na medida do necessário para a criação de mecanismos e estruturas que evitem que os investidores e o mercado possam ser lesados.

O excesso de regulação impede que os agentes possam ter espaço para desenvolver suas atividades e negócios de forma criativa e inovadora, engessando o desenvolvimento do mercado. Por outro lado, a falta de regulação coloca em risco não apenas o público investidor, mas a própria existência e confiabilidade do mercado de capitais. O desafio que constantemente autoridade reguladora e agentes privados devem enfrentar é encontrar o equilíbrio entre esses dois pontos. Como diria PARACELSO, a diferença entre o remédio e o veneno está na dose $\mathrm{e}^{771}$.

Espera-se que esse trabalho possa ser útil para os esforços de compreensão de que como o sistema de registro obrigatório e as hipóteses de dispensa é estruturado no Brasil e quais são suas bases teóricas, assim como para contribuir com as discussões em torno da necessidade de contínua revisão, atualização e sistematização das instruções normativas da CVM que disciplinam ofertas públicas de distribuição de valores mobiliários.

$$
* * *
$$

771 "Todas as substâncias são venenos, não existe nada que não seja veneno. Somente a dose corrente diferencia o veneno do remédio". Frase atribuída à Paracelso (1493-1541), cujo nome verdadeiro é Phillipus Aureolus Theophrastus Bombastus von Hohenheim. 


\section{BIBLIOGRAFIA}

1. AKERLOF, George A. The market for lemons: quality uncertainty and the market mechanism. In: The Quarterly Journal of Economics, Oxford, vol. 84, n. ${ }^{o}$ 3, 1970.

2. AMERICAN BAR ASSOCIATION. Report on State Merit Regulation of Securities Offerings. In: The Business Lawyer, vol. 41, n. 3 , maio de 1986.

3. ARAGÃO, Paulo Cézar. Novos Aspectos dos Valores Mobiliários na Lei das Sociedades por Ações. In: Revista dos Tribunais, ano 73, vol. 584, jun. 1984.

4. BENSTON, George J. An Appraisal of the costs and benefits of governmentrequired disclosure: SEC and FTC Requirements. In: Law and Contemporary Problems, vol. 41, n. ${ }^{\circ}$ 3, 1977.

5. BENSTON, George J. Required disclosure and the stock market: an Evaluation of the Securities Exchange Act of 1934. In: The American Economic Review, vol. 63, n. ${ }^{\circ} 1$, mar. 1973.

6. BERLE JR., Adolf Augustus; MEANS, Gardiner C. The Modern Corporation and Private Property. New Brunswick: Transaction Publishers, 2007, 9ª reimpressão.

7. BLACK, Bernard S. Strengthening Brazil's Securities Market. In: Revista de Direito Mercantil, Industrial, Econômico Financeiro, n. ${ }^{\circ}$ 120, out./dez. de 2000.

8. BOCATER, Maria Isabel do Prado; LOIOLA, Leandro. Aspectos atuais da regulamentação de distribuições públicas de títulos e valores mobiliários. In: Revista de Direito Bancário e do Mercado de Capitais, vol. 53, jul. 2011.

9. BUSCHINELLI, Gabriel Saad Kik. Comentários aos arts. 19 e 20 da Lei $n$ 6.385/76. In: CODORNIZ, Gabriela; PATELLA, Laura (coord.). Comentários à Lei do Mercado de Capitais (Lei n 6.385/76). São Paulo: Quartier Latin, 2015. 
10. CÂMARA, Paulo. Manual de direito dos valores mobiliários. Coimbra: Almedina, 2009.

11. CARVAlHOSA, Modesto. Comentários à Lei das Sociedades Anônimas, vol. 3, $6^{\mathrm{a}}$ ed. São Paulo: Saraiva, 2014.

12. CARVALHOSA, Modesto. Oferta pública de aquisição de ações. Rio de Janeiro: IBMEC, 1979.

13. CATAPANI, Márcio Ferro. Títulos públicos: natureza jurídica e mercado - LFTs, LTNs, NTNs, TDAs e Tesouro Direto. São Paulo: Quartier Latin, 2014.

14. CEREZETTI, Sheila Christina Neder. Capítulo $7-$ Os Deveres $e$ Responsabilidades dos Administradores das Companhias Abertas Brasileiras. In: GOMES DE ARAÚJO, Danilo Borges dos Santos (coord.). Regulação Brasileira do Mercado de Capitais. São Paulo: Saraiva, 2015.

15. CHOI, Stephen. Regulating Investors Not Issuers: a Market-Based Proposal. In: California Law Review, vol. 88, 2000.

16. CLARK, Robert Charles. Corporate Law. Nova York: Aspen Law \& Business, 1986.

17. COASE, R. H. The problem of social cost. In: Journal of Law and Economics, vol. 3., 1960.

18. CODORNIZ, Gabriela; PATELLA, Laura; Copola, Marina; Comentários ao art. $2^{o}$ da Lei $n$ 6.385/76. In: CODORNIZ, Gabriela; PATELLA, Laura (coord.). Comentários à Lei do Mercado de Capitais (Lei n 6.385/76). São Paulo: Quartier Latin, 2015.

19. COFFEE JR. John C.; SALE, Hillary A., HENDERSON, M. Todd. Securities Regulation, cases and materials. Saint Paul: Foundation Press, 13ª edição, 2015. 
20. COFFEE JR., John C. Market Failure and the Economic Case for a Mandatory Disclosure System. In: Virginia Law Review, vol. 70, n. ${ }^{\circ}$ 4, 1984.

21. COHEN, Milton. Truth in Securities Revisited. In: Harvard Law Review, 1966.

22. COMPARATO, Fábio Konder. A regra do sigilo nas ofertas públicas de aquisição de ações. In: Revista da CVM, vol. I, n. ${ }^{\circ}$ 1, jan./abr. 1983.

23. COMPARATO, Fábio Konder. As ações de sociedade anônima como valores mobiliários - natureza e efeitos do registro acionário in Novos Ensaios e Pareceres de Direito Empresarial. Rio de Janeiro: Forense, 1981.

24. CORDEIRO FILHO, Ari. Manual de Abertura das Companhias. Rio de Janeiro: IBMEC/APEC, 1981

25. DA COSTA, Ana Paula Paulino. Casos de Fraudes Corporativas Financeiras: antecedentes, recursos substantivos e simbólicos relacionadas. Tese de Doutorado. São Paulo: FGV, Escola de Administração, 2011.

26. DIAS, Luciana Pires. Transparência como estratégia regulatória no mercado de valores mobiliários: um estudo empírico das transações com partes relacionadas. Tese de Doutorado. São Paulo: Faculdade de Direito da Universidade de São Paulo, 2014.

27. DOUGLAS, William O. Investor protection. In: Yale Review, 1934.

28. DUBEUX, Júlio Ramalho. A Comissão de Valores Mobiliários e os principais instrumentos regulatórios do mercado de capitais brasileiro. Editor Sergio Antonio Fabris: Porto Alegre, 2006.

29. DUBEUX, Júlio Ramalho. Registro na CVM não garante o sucesso do investimento: precedente judicial no "Caso Boi Gordo", 2007. Disponível em: Portal do Investidor da CVM http://www.portaldoinvestidor.gov.br/portaldoinvestidor/export/sites/portaldoinve 
stidor/entrevistas/Arquivos/AlexandrePinheiro/Registro_na_CVM_nxo_garante_o sucesso_do_investimento.PDF.

30. EASTERBROOK, Frank H. FISCHEL, Daniel R. Mandatory Disclosure and the Protection of Investors. In: Virginia Law Review 669, vol. 70, 1984.

31. EASTERBROOK, Frank; FISCHEL, Daniel R. The economic structure of corporate law. Cambridge: Harvard University Press, 1996.

32. EIZIRIK, Nelson. As lições do "Caso Vale”. In: Revista Brasileira de Mercado de Capitais, vol. 6, n. ${ }^{\circ}$ 6, jan./abr. 1980.

33. EIZIRIK, Nelson. Caracterização Jurídica da Emissão Pública de Valores Mobiliários. In: Revista de Direito Mercantil Industrial, Econômico e Financeiro, n. ${ }^{\circ} 83$, jul./set., 1991.

34. EIZIRIK, Nelson. Emissão de Debêntures. In: Revista dos Tribunais, vol. 721, nov. 1995.

35. EIZIRIK, Nelson. O papel do Estado na Regulação do Mercado de Capitais. Rio de Janeiro: IBMEC, 1977.

36. EIZIRIK, Nelson; GAAL, Ariádna B.; PARENTE, Flávia. Mercado de Capitais Regime Jurídico, $2^{\mathrm{a}}$ ed. Rio de Janeiro: Renovar, 2008.

37. FAMA, Eugene F. Efficient Capital Markets: A review of theory and empirical work in The Journal of Finance. New York: vol. 25, n. ${ }^{\circ}$ 2, 1970.

38. FERRELL, Allen. The case for mandatory disclosure in securities regulation around the world. In: Harvard Law School John M. Olin Center for Law, Economics and Business Discussion Paper Series, Paper n. ${ }^{\circ}$ 492, 2004.

39. FLEMING, Rick A. 100 Years of Securities Law: Examining A Foundation Laid in the Kansas Blue Sky Law. In: Washburn Law Journal, vol. 50, 2011. 
40. FLETCHER III, C. Edward. Sophisticated Investors Under the Federal Securities Laws. In: Duke Law Journal, 1988.

41. FOX, Merritt. B. The issuer choice debate. In: Theoretical Inquiries in Law 2.2, 2001.

42. FOX, Merritt B. Retaining Mandatory Securities Disclosure: Why issuer choice is not investor empowerment. In: Virginia Law Review, vol. 85, n. ${ }^{\text {7, out. } 1999 .}$

43. FRANCO, Vera Helena de Mello. Teoria geral do contrato: confronto com o direito europeu futuro. São Paulo: RT, 2011.

44. GOMES DE ARAÚJO, Danilo Borges dos Santos. Mercado de capitais: definição, funções, objetivos e histórica da regulação brasileira. In: GOMES DE ARAÚJO, Danilo Borges dos Santos (coord.). Regulação Brasileira do Mercado de Capitais. São Paulo: Saraiva, 2015.

45. GOWER, Lawrence C. B; DAVIES, Paul L. Principles of Modern Company Law, 9aed. London: Sweet \& Maxwell, 2012.

46. KRAAKMAN, Reinier et. al. The anatomy of corporate law: a comparative and functional approach, $2^{\mathrm{a}}$ ed. New York: Oxford University Press, 2009.

47. KRIPKE, Homer. The SEC and Corporate Disclosure: regulation in search of a purpose. New York: Law \& Business, Inc, 1979.

48. KRONMAN, Anthony T. Mistake, disclosure, information and the law of contracts. In: The Journal of Legal Studies, vol. 7, n. ${ }^{\circ}$, janeiro de 1978.

49. LEÃES, Luiz Gastão Paes de Barros. Mercado de Capitais \& "Insider Trading”. São Paulo: RT, 1982. 
50. LEÃES, Luiz Gastão Paes de Barros. O conceito de "security" no direito norteamericano e o conceito análogo no direito brasileiro. In: Revista de Direito

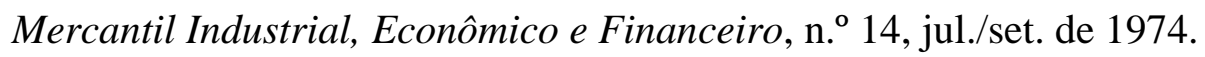

51. LOBO, Jorge. As 'Dez Regras de Ouro' dos Títulos Cambiais. In: Revista da EMERJ, v.3, n. 9, 2000.

52. LOSS, Louis. O papel do governo na proteção dos investidores. In: Revista de Direito Mercantil, Industrial, Econômico e Financeiro, n. ${ }^{\circ}$ 58, abr./jun. 1985.

53. LOSS, Louis; SELIGMAN, Joel. Fundamentals of Securities Regulation, $5^{\mathrm{a}}$ ed. Nova York: Aspen, 2004.

54. MATTOS FILHO, Ary Oswaldo. Direito dos valores mobiliários, vol. I, tomo I. São Paulo: FGV, 2015.

55. MATTOS FILHO, Ary Oswaldo. O conceito de valor mobiliário. In: Revista de Direito Mercantil Industrial, Econômico e Financeiro, n. ${ }^{\circ}$ 59, jul./set. de 1985.

56. MELlO, Pedro Carvalho de. Regulamentação econômica e divulgação de informações das empresas. In: Revista da CVM, vol. I, n. ${ }^{\circ}$, jan./abr. 1983.

57. MOTTA, Rita de Cássia Luz Teixeira. O conceito de valor mobiliário no direito brasileiro. Dissertação de Mestrado. São Paulo: Faculdade de Direito da Universidade de São Paulo, 2002.

58. NUSDEO, Fabio. Curso de economia: introdução ao direito econômico, $5^{\mathrm{a}}$ ed. São Paulo: RT, 2008.

59. OIOLI, Erik Frederico. Oferta pública de aquisição do controle de companhias abertas. São Paulo: Quartier Latin, 2010. 
60. OIOLI, Erik Frederico; AMARAL, José Romeu G. O conceito de oferta pública como elemento delineador do regime jurídico dos valores mobiliários. In: Revista de Direito das Sociedades e dos Valores Mobiliários, n. ${ }^{\circ}$, novembro de 2015.

61. PALMITER, Alan. Toward disclosure choice in Securities Offerings. In: Columbia Business Law Review, 1999.

62. PAREDES, Troy A. Blinded by the Light: information overload and its consequences for securities regulation. In: Washington University Law Review, vol. 81, 2003.

63. PECORA, Ferdinand. Wall Street Under Oath: the story of our modern money changers. New York: Simon and Schuster, 1939.

64. PIGOU, A. The Economics of Welfare. London: MacMillan, 1938.

65. PITTA, André Grünspun. Comentários ao art. 21 da Lei $n$ 6.385/76. In: CODORNIZ, Gabriela; PATELLA, Laura (coord.). Comentários à Lei do Mercado de Capitais (Lei n 6.385/76). São Paulo: Quartier Latin, 2015.

66. PITTA, André Grünspun. $O$ regime de informação das companhias abertas. São Paulo: Quartier Latin, 2013.

67. PITTA, André Grünspun. Aspectos jurídicos do processo de formação de capital por meio do mercado de valores mobiliários: as alternativas de organização e capitalização das sociedades empresárias. Tese de Doutorado. Faculdade de Direito, Universidade de São Paulo, São Paulo, 2017

68. PONTES DE MIRANDA, Francisco Cavalcanti. Tratado de Direito Privado, $3^{\mathrm{a}}$ ed., tomo 38. São Paulo: RT, 1984, p. 27.

69. PRADO, Roberta Nioac. Oferta pública de ações obrigatória nas S.A: tag along. São Paulo: Quartier Latin, 2005. 
70. ROMANO, Roberta. Empowering investors: a market approach to securities regulation. In: The Yale Law Journal, vol. 107, n. ${ }^{\circ}$ 8, junho de 1998.

71. SALOMÃO FILHO, Calixto. $O$ novo direito societário, $4^{\mathrm{a}}$ ed. São Paulo: Malheiros, 2011.

72. SELIGMAN, Joel. The historical need for a mandatory corporate disclosure system. In: The Journal of Corporate Law, vol. 9, n. ${ }^{\circ}$ 1, 1983.

73. SELIGMAN, Joel. The transformation of Wall Street. A history of the Securities and Exchange Commission and Modern Corporate Finance, $3^{\mathrm{a}}$ ed. New York: Wolters Kluwer Law \& Business, 2003.

74. SILVA, Sueli da. Colocação de ações entre empregados da companhia (parecer sobre registro de emissão). In: Revista da CVM, v. 6, n. 21, jul./set.1988.

75. SZTAJN, Rachel. Conceitos de liquidez na disciplina do mercado de valores mobiliários. In: Revista de Direito Mercantil, Industrial, Econômico e Financeiro. n. ${ }^{\circ} 126$, abr./jun. 2002.

76. SZTAJN, Rachel. Regulação e o Mercado de Valores Mobiliários. In: Revista de Direito Mercantil, Industrial, Econômico e Financeiro, n. ${ }^{\circ}$ 135, jul./set. 2004.

77. TEIXEIRA, Egberto Lacerda. GUERREIRO, José Alexandre Tavares. Das Sociedades Anônimas no Direito Brasileiro, vols. 1 e 2. São Paulo: José Bushatsky, 1979.

78. TRINDADE, Marcelo Fernandez. Oferta ao Público de Unidades Autônomas de Empreendimento Imobiliário. Não Caracterização como Emissão ou Oferta Pública de Valores Mobiliários. In: Revista Brasileira de Direito Civil, vol. 11, jan./mar. 2017. 
79. WALD, Arnoldo. Dos conceitos de emissão e de oferta pública na legislação do mercado de capitais. In: Revista de Direito Mercantil Industrial, Econômico e Financeiro, vol. 11, n. ${ }^{\circ}$ 8, 1972.

80. WALD, Arnoldo; EIZIRIK, Nelson. Responsabilidade do Underwriter pela Veracidade das Informações em uma Emissão Pública. In: Revista da CVM, vol. 2, n. ${ }^{\circ}$ 5, mai./ago. 1984.

81. WALD, Arnoldo. O investidor qualificado no mercado de capitais brasileiro. In: Revista de Direito Bancário e do Mercado de Capitais, n. 32, abr./jun. 2006.

82. YAZBEK, Otavio. Regulação do mercado financeiro e de capitais. Rio de Janeiro: Elsevier, 2007.

83. ZANETTI, Cristiano de Souza. Responsabilidade pela ruptura das negociações. São Paulo: Editora Juarez de Oliveira, 2005.

84. ZINGALES, Luigi. The costs and benefits of financial market regulation. ECGI Law Working Paper n. ${ }^{\circ}$ 21/2004, Abril de 2004.

$$
* * *
$$

